\title{
AGAMA DI TENGAH ARUS INDUSTRI PARIWISATA DI LOMBOK: Kajian tentang Religiusitas Masyarakat Muslim di Kawasan Wisata Senggigi
}

\section{Mustain*}

\begin{abstract}
Abstrak: Keberadaan pariwisata di Lombok mengalami perkembangan yang cukup pesat, khususnya di kawasan Senggigi. Dengan pendekatan kualitatif-deskriptif, artikel ini berupaya mendeskripsikan bagaimana interaksi masyarakat muslim kawasan wisata Senggigi dengan kegiatan pariwisata dan bagaimana aktifitas keagamaan masyarakat muslim yang tinggal di kawasan industri pariwisata tersebut. Hasil penelitian menunjukkan bahwa interaksi masyarakat muslim kawasan wisata Senggigi dengan kegiatan pariwisata yang berlangsung di wilayah tempat tinggalnya secara umum berlangsung secara pasif. Hanya sebagaian dari mereka, khususnya para pekerja di pusat-pusat industri pariwisata yang secara intens berinteraksi, khususnya dengan para wisatawan. Oleh karena itu pertukaran nilai-nilai budaya hanya berlangsung pada kelompok ini. Sedangkan masyarakat pada umumnya tetap berada dalam dunia mereka yang diliputi dengan keyakinan dan tradisi agama yang dianutnya. Keberadaan pariwisata yang menghadirkan orang dengan berbagai nilai dan budaya yang beragam tidak banyak menyentuh kehidupan keberagamaan mereka. Masyarakat muslim tetap melaksanakan aktivitas keagamaan mereka sebagaimana yang telah ditunaikannya selama ini.
\end{abstract}

Kata kunci: industri pariwisata, religiusitas, masyarakat muslim

\section{Pendahuluan}

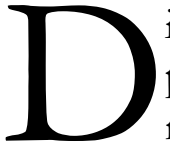

i berbagai wilayah di Nusa Tenggara Barat termasuk di pulau Lombok, pengembangan industri pariwisata menjadi salah satu cara yang dilakukan untuk meningkatkan pendapatan masyarakat. Untuk memberikan

* Penulis adalah Dosen Tetap PAI FTK UIN Mataram, e-mail: mustainrema@yahoo.com 
landasan hukum pengembangan pariwisata, kebijakan pemerintah itu dituangkan dalam peraturan daerah (perda), baik pemerintah propinsi maupun pemerintah kabupaten.

Di antaranya adalah Peraturan Daerah (Perda) No.9 Tahun 1989 tanggal 15 Agustus 1989. Di dalam peraturan daerah tersebut pemerintah Provinsi NTB telah menetapkan 15 kawasan potensial untuk dikembangkan. Terdapat 9 kawasan di Pulau Lombok dan 6 kawasan di Pulau Sumbawa. Kawasan pariwisata di Pulau Lombok terdiri atas; (1) kawasan Sire, Gili Air, Gili Meno, Gili Trawangan, Senggigi dan sekitarnya; (2) kawasan Suranadi dan sekitarnya; (3) kawasan Gili Gede dan sekitarnya; (4) kawasan Kuta, Seger Ann dan sekitarnya; (5) kawasan Selong Belanak dan sekitarnya; (6) kawasan Rinjani dan sekitarnya; (7) kawasan Gili Indah dan sekitarnya; (8) kawasan Gili Sulat dan sekitarnya; (9) kawasan Dusun Sade dan sekitarnya. Kawasan pariwisata di Pulau Sumbawa terdiri atas; (1) kawasan Pulau Moyo dan sekitarnya; (2) kawasan Pantai Maluk dan sekitarnya; (3) Pantai Hu'u dan sekitarnya; (4) kawasan Sape dan sekitarnya; (5) kawasan Teluk Bima dan sekitarnya; (6) kawasan Gunung Tambora dan sekitarnya. Semua kawasan wisata yang dikembangkan berbasiskan wisata alam, sejarah, dan budaya.

Untuk semakin meningkatkan perkembangan pariwisata di Nusa Tenggara Barat, pada tahun 2013 pemerintah provinsi Nusa Tenggara Barat mengeluarkan peraturan daerah (Perda) Nomor 7 Tahun 2013 tentang Rencana Induk Pembangunan Kepariwisataan Daerah Tahun 2013-2028. Dalam peraturan daerah tersebut disebutkan tentang adanya Kawasan Strategis Pariwisita Daerah (KSPD). KSPD adalah kawasan yang memiliki fungsi utama pariwisata atau memiliki potensi untuk pengembangan pariwisata nasional yang mempunyai pengaruh penting dalam satu atau lebih aspek, seperti pertumbuhan ekonomi, sosial dan budaya, pemberdayaan sumber daya alam, daya dukung lingkungan hidup, serta pertahanan dan keamanan.

Pemerintah kabupaten Lombok Barat juga mengeluarkan kebijakan terkait dengan pengaturan pariwisata dalam bentuk 
peraturan daerah, yaitu Peraturan Daerah (PERDA) Kabupaten Lombok Barat Nomor 11 tahun 2011 tentang Rencana Tata Ruang Wilayah Kabupaten Lombok Barat Tahun 2011-2031. Dalam Bab V tentang Rencana Pola Ruang Wilayah, Bagian Ketiga Kawasan Budi Daya, Pasal 26 disebutkan bahwa kawasan peruntukan pariwisata sebagaimana dimaksud pada Pasal 19 huruf g diarahkan pada: pertama, kawasan wisata alam direncanakan di Pantai Senggigi dan sekitarnya, Kawasan pantai Sekotong dan sekitarnya, Kawasan Gili Kedis, Gili Sudaq, Gili Tangkong, Gili Nanggu, Gili Poh, Gili Genting, Gili Lontar, Gili Gede, Gili Rengit, Gili Layar, Gili Asahan, Gili Goleng, Gili Kao, Gili Kere, Gili Sepatang/ Sophialouisa, Gili Geneng-Geneng, Gili Anak Ewok, Gili Sarang, Gili Wayang, Gili Pulau Tiga, Gili Tepong, Gili Batu Nyangkong, dan Gili Malang, Pantai Induk, Pantai Cemare, Pantai Kuranji, Gunung Pengsong, Kawasan Suranadi, dan Kawasan Wisata Sesaot; kedua, kawasan wisata budaya direncanakan pada Kawasan Taman Narmada, Kawasan Taman Lingsar, Kawasan Kerajinan Gerabah Banyumulek di Kecamatan Kediri; ketiga, kawasan wisata buatan direncanakan pada kecamatan yang memiliki potensi untuk dikembangan; dan keempat, pengelolaan kawasan peruntukan pariwisata mengacu pada peraturan perundangan yang berlaku.

Merujuk pada peraturan daerah tentang tata ruang wilayah Kabupaten Lombok Barat di atas, maka kawasan Senggigi termasuk dalam wilayah pengembangan wisata alam. Bahkan kawasan wisata Senggigi memberi sumbangan terbesar bagi Pendapatan Asli Daerah (PAD) Lombok Barat. Tahun 2014. Dari PAD Kabupaten Lombok Barat tahun 2014 yang berjumlah 140 milyar, 50-60 \% disumbang dari bidang pariwisata, khususnya kawasan Senggigi, Narmada, dan Sekotong (Pariwisata Sumbang 60\% PAD”, dalam http:/ / bali.bisnis.com/read/20150415/20/50981/url).

Kawasan Senggigi, sebagaimana disebutkan dalam Website Pemerintah Desa Senggigi, secara administratif, kawasan Senggigi masuk wilayah Desa Senggigi Kecamatan Batulayar Kabupaten Lombok Barat. Luas wilayah Desa Senggigi mencapai 1703 hektar yang terbagi ke dalam empat dusun, yaitu Dusun Mangsit, Dusun 
Kerandangan, Dusun Sengigi, dan Dusun Loco. Penduduk Desa Senggigi berjumlah 4725 jiwa dengan komposisi jenis kelamin perempuan 2342 jiwa (57 \%) dan laki-laki 2383 jiwa (50,43\%). Agama Islam dipeluk oleh mayoritas penduduk Desa Senggigi yang berjumlah 4354 jiwa (92,15\%), kemudian pemeluk agama Hindu berjumlah 312 jiwa (6,60\%), pemeluk Protestan berjumlah 37 jiwa $(0,78 \%)$, pemeluk Katholik berjumlah 19 jiwa (0,40\%), dan pemeluk Budha berjumlah 3 jiwa $(0,06 \%)$ (http:/ / senggigi.desa.id/index.php/ first/artikel/102).

Apabila melihat pada komposisi penduduk kawasan Senggigi dari segi agama, sebagian besarnya adalah umat Islam. Hal itu berarti bahwa yang akan merasakan terjadinya perubahanperubahan yang diakibatkan adanya industri pariwisata di wilayah tersebut adalah mereka yang beragama Islam. Perubahanperubahan yang terjadi tidak hanya bersangkut paut dengan bidang ekonomi, sosial, dan budaya, tetapi juga bersinggungan dengan aspek kehidupan keagamaan (religiusitas).

Oleh karena itu penelitian ini mengkaji berbagai persoalan terkait dengan relasi antara masyarakat muslim Senggigi dengan industri wisata yang ada di tempat tinggal mereka. Pada satu sisi, mereka dituntut untuk terus berpegang pada keyakinan, pengetahuan, dan pemahaman agama yang mereka peluk. Namun pada sisi yang lain, perubahan-perubahan yang timbul dari aktifitas industri pariwisata menuntut untuk disikapi secara tepat. Kondisi seperti di atas memposisikan mereka pada situasi-situasi dilematis yang mungkin saja dapat menimbulkan ketegangan dalam kehidupan personal maupun kelompok. Ketegangan-ketegangan dapat muncul karena perbedaan respons antara mereka yang bersikap resistens dan yang bersikap akomodatif terhadap perubahan yang terjadi. Selanjutnya penelitian ini mengkaji dua hal, yaitu: bagaimana interaksi masyarakat muslim kawasan wisata Senggigi dengan kegiatan pariwisata yang berlangsung di wilayah tempat tinggalnya dan bagaimanakah aktifitas keagamaan masyarakat muslim yang tinggal di kawasan tersebut. 


\section{Metode penelitian}

Metode yang digunakan dalam penelitian ini yaitu kualitatifekploratif-deskriptif. Penelitian kualitatif sebagaimana yang didefinisikan oleh Bogdan dan Taylor (1992:137-139) mengacu pada prosedur pendeskripsian data tertulis, pembicaraanpembicaraan, dan mengamati perilaku. Dalam penelitian kualitatif, sumber data mencakup dua hal, yaitu subjek (pelaku) dan informan. Subjek atau pelaku adalah seseorang yang menjadi objek pengamatan dalam suatu setting alamiah, sementara informan adalah siapa saja yang dapat memberikan keterangan atau data berkaitan dengan topik yang sedang diteliti (Spradley, 1997:44). Pemilihan informan didasarkan atas kompetensi mereka dan bukan atas representativeness (keterwakilan) (Bernard, 1995:165). Informan dipilih dengan teknik purposive sampling dan snowball sampling (Babbie, 1998:194-196). Sehingga kriteria pemilihan informan didasarkan pada kapasitasnya dalam memberikan informasi yang dibutuhkan. Pilihannya adalah pada siapa yang paling mungkin memberikan data yang memadai untuk menjelaskan permasalahan yang sedang diteliti.

Kegiatan pengumpulan data penelitian ini dilakukan dengan menggunakan metode observasi, wawancara, dan dokumentasi. Dalam konteks penelitian ini, target observasi yaitu lokasi yang menjadi pusat kegiatan-kegiatan keagamaan yang terdapat di kawasan wisata Senggigi, seperti masjid, musholla, dan madrasah. Yang diamati adalah terkait dengan ketersediaan sarana dan prasarana yang mendukung kegiatan keagamaan. Selanjutnya juga para pelaku dan aktifitas pelaku, yang dalam penelitian ini difokuskan kepada masyarakat muslim yang tinggal di kawasan wisata Senggigi. Aktifitas yang diamati yaitu mencakup aktifitas ritual dan sosial keagamaan.

Data-data yang digali dengan wawancara adalah terkait dengan informasi tentang perubahan-perubahan dalam aspek ritual dan sosial keagamaan yang terjadi pada masyarakat muslim yang tinggal di kawasan wisata Senggigi. Selain itu juga terkait dengan bentukbentuk kegiatan ritual dan sosial keagamaan yang sebelumnya 
dilakukan dan kemudian hilang, yang masih bertahan, dan yang baru muncul.

Dokumentasi digunakan untuk menggali data-data yang bersumber dari dokumen terkait dengan data kependudukan, kegiatan ritual dan sosial keagamaan yang dilaksanakan oleh masyarakat muslim yang tinggal di kawasan wisata Senggigi. Dokumen dimaksud dapat berupa tulisan dan foto-foto kegiatan ritual dan sosial keagamaan.

Selanjutnya peneliti menerapkan metode analisis data penelitian kualitatif yang mencakup tiga kegiatan, yaitu reduksi data, display data, dan pengambilan kesimpulan dan verifikasi. Ketiga kegiatan tersebut saling berhubungan dan berlangsung terus selama penelitian dilakukan. Reduksi data oleh peneliti mencakup proses memilih, memilah, menfokuskan, menyederhanakan, mengabstraksi, dan mentransformasikan data mentah yang diperoleh dari lapangan. Hasil yang dicapai dari reduksi data adalah data yang lebih mudah dikendalikan dan memberi gambaran yang lebih tajam. Display data mencakup kegiatan untuk lebih mengendalikan data dengan membuatkan berbagai macam matriks, grafik, dan bagan. Kesimpulan dilakukan peneliti dengan berpijak pada pola, tema, hubungan, persamaan, hal-hal yang kerap muncul, hipotesis, dan lain-lain. Kesimpulan pada awalnya bersifat tentatif, dan terus diverifikasi, baik dengan trianggulasi metode dan sumber, perpanjangan kehadiran, dan mendiskusikan temuan yang ada dengan pihak-pihak yang berkompeten.

\section{Kerangka Teoritik}

1. Religiusitas

Jalaluddin mendefinisikan religiusitas sebagai keadaan yang ada dalam diri seseorang yang mendorongnya untuk bertingkah laku sesuai dengan kadar ketaatannya terhadap agama yang dipeluknya. Karena merupakan wujud perilaku beragama, maka religiusitas bersumber langsung ataupun tidak langsung kepada nash (Jalaludin, 2001:89). 
Kartini Kartono menyebut religiusitas sebagai perasaan religious, yaitu perasaan berkaitan dengan Tuhan atau Yang Maha Kuasa, antara lain takjub, kagum, percaya, iman, tawakal, pasrah diri, rendah hati ketergantungan pada Ilahi, merasa diri sangat kecil, kesadaran akan dosa dan lain-lain (Kartini, 2003:124).

Definisi lain tentang religiusitas diungkapkan oleh Glock dan Strak dalam Polutzian. Ia menyebutkan bahwa relegiusitas sebagai religius commitment (yang berhubungan dengan agama atau keyakinan iman) yang dapat dilihat melalui aktivitas atau perilaku individu yang bersangkutan dengan agama atau keyakinan iman yang dianut (Poloutzian, 1996:77).

Dari beberapa definisi tersebut di atas, religiusitas atau keberagamaan merupakan gambaran tentang bagaimana penganut agama menghayati dan mengamalkan agama yang dipeluknya. Agama menyediakan seperangkat ajaran dan doktrin yang mengatur bagaiman manusia mesti hidup di dunia. Para penganut agama menjadikan ajaran dan doktrin itu sebagai panduan dalam berperilaku. Perilaku yang dijalankan oleh penganut agama merupakan wujud wujud praktis dari kesadaran dan peneriman dalam hati akan keberadaan Tuhan dengan keseluruhan ajaran dan doktrinnya.

Glock dan Stark dalam Poloutzian (1996:78), menyebutkan lima dimensi religiusitas, yaitu: religious practice (the ritualistic dimension), religious belief (the ideological dimension), religious knowledge (the intellectual dimension), religious feeling (the experiental dimension), religious effect (the consequential dimension). Religius practice berwujud dalam bentuk ritual-ritual peribadatan dalam agama, seperti shalat, puasa, dan ritual berdo'a. Religious belief terkait dengan sikap pengakuan dan penerimaan akan keberadaan Allah dan keseluruhan ajaran serta doktrinnya, terutama terkait dengan hal yang ghaib. Religious knowledge merupakan pengetahuan dan pemahaman terhadap ajaran-ajaran agama. Religious feeling terkait dengan pengalaman-pengalaman kejiwaan dalam merasakan kehadiran Allah. Religious effect merupakan wujud perilaku yang muncul karena dimotivasi kesadaran terhadap kewajiban-kewajiban dalam agama. 
Menurut Ancok dan Suroso (1994), rumusan Glock \& Stark yang membagi keberagamaan menjadi lima dimensi dalam tingkat tertentu mempunyai kesesuaian dalam Islam yaitu: dimensi keyakinan atau akidah Islam menunjuk pada seberapa tingkat keyakinan muslim terhadap kebenaran ajaran-ajaran agamanya, terutama terhadap ajaranajaran yang bersifat fundamental dan dogmatik. Di dalam keberislaman, isi dimensi keimanan menyangkut keyakinan tentang Allah, para Malaikat, Nabi/Rasul, kitab-kitab Allah, surga dan neraka, serta qadha' dan qadar. Dimensi peribadatan (praktek agama) atau syariah menunjuk pada seberapa tingkat kepada Tuhan muslim dalam mengerjakan kegiatankegiatan ritual sebagaimana disuruh dan dianjurkan oleh agamanya. Dalam keberIslaman, dimensi peribadatan menyangkut pelaksanaan shalat, puasa, zakat, haji, membaca Al-qur'an, do'a, zikir, ibadah kurban, iktikaf di masjid pada bulan puasa. Dimensi pengamalan atau akhlak menunjuk pada seberapa tingkatan muslim berperilaku dimotivasi oleh ajaran-ajaran agamanya, yaitu bagaimana individu berelasi dengan dunianya, terutama dengan manusia lain. Dalam keberIslaman, dimensi ini meliputi perilaku suka menolong, bekerjasama, berderma, mensejahterakan dan menumbuhkembangkan orang lain, menegakkan keadilan dan kebenaran, berlaku jujur, memaafkan, menjaga lingkungan hidup, menjaga amanat, tidak mencuri, tidak korupsi, tidak menipu, tidak berjudi, tidak meminum-minuman yang memabukkan, mematuhi normanorma Islam dalam perilaku seksual, berjuang untuk hidup sukses menurut ukuran Islam. Dimensi pengetahuan atau ilmu menunjuk pada seberapa tingkat pengetahuan dan pemahaman muslim terhadap ajaranajaran agamanya, terutamam mengenai ajaran-ajaran pokok dari agamanya, sebagaimana termuat dalam kitab sucinya. Dalam keberIslaman, dimensi ini menyangkut pengetahuan tentang isi Al-Qur'an, pokok-pokok ajaran agama yang harus diimani dan dilaksanakan (rukun Islam dan rukun iman), hukum-hukum Islam, sejarah Islam. Sedangkan dimensi pengalaman atau penghayatan adalah dimensi yang menyertai keyakinan, pengamalan, dan peribadatan. Dimensi penghayatan 
menunjuk pada seberapa jauh tingkat muslim dalam merasakan dan mengalami perasaan-perasaan dan pengalaman-pengalaman religius. Dalam keberislaman, dimensi ini terwujud dalam perasaan dekat dengan Allah, merasa do'a-do'anya sering terkabul, perasaan tentram bahagia karena menuhankan Allah, perasaan bertawakkal (pasrah diri secara positif) kepada Allah, perasan khusuk ketika melaksanakan shalat atau berdo'a, perasaan tergetar ketika mendengar adzan atau ayat-ayat Al-Qur'an, perasaan bersyukur kepada Allah, perasaan mendapat peringatan atau pertolongan dari Allah.

\section{Industri Pariwisata dan Perubahan Sosial}

Perkembangan industri pariwisata yang semakin pesat pada gilirannya mengakibatkan terjadinya perubahan masyarakat dalam berbagai aspeknya. Menurut Gillin dan Gillin, sebagaimana dikutip setiadi dan Kolip (2011:610), perubahan sosial merupakan suatu variasi dari cara-cara hidup yang telah diterima yang disebabkan berbagai hal. Dalam makna perubahan sosial tercakup berbagai ekspresi mengenai struktur seperti norma, nilai, dan fenomena kultural (Lauer, 2003:4).

Perubahan sosial yang terjadi dapat berupa kemajuan maupun kemunduran, terjadi dalam aspek yang luas maupun terbatas, dan bisa berlangsung secara cepat maupun lambat (Nazsir, 2008:157). Selain itu perubahan sosial juga dapat terjadi karena kondisi geografis, kebudayan materil, komposisi penduduk, ideology maupun karena adanya difusi maupun penemuan-penemuan baru dalam masyarakat tersebut (Setiadi dan Kolip, 2011:610). Sedangkan menurut Soekanto terjadinya perubahan sosial dapat terjadi karena beberapa faktor, yaitu: kontak dengan kebudayaan lain, pendidikan yang makin maju, keinginan untuk maju, keterbukaan dalam masyarakat, pergaulan dengan kelompok yang semakin heterogen, dan ketidakpuasan terhadap kondisi yang sedang berlangsung (Soekanto, 2007:287).

Perubahan sosial yang terjadi pada individu atau kelompok merupakan hasil dari interpretasi atas kenyataan yang sedang terjadi. Interpretasi itu kemudian menghasilkan definisi bersama 
mengenai struktur dan institusi sosial. Kesamaan interpretasi tentang kenyataan itu selanjutnya mengarahkan tindakan-tindakan dan pola-pola interaksi dalam kelompok (Soeprapto, 2002:88-89). Kesamaan interpretasi tentang kenyataan itu selanjutnya mengarahkan tindakan-tindakan dan pola-pola interaksi dalam kelompok (Soeprapto, 2002:88-89). Dalam perspektif interaksionisme simbolis, manusia bertindak berdasarkan pada makna apa yang ada pada sesuatu itu bagi dirinya. Makna berasal dari interaksi seseorang dengan orang lain, dan makna-makna disempurnakan dalam proses interaksi yang sedang berlangsung (Soetomo, 2008:124).

Ketika melakukan interpretasi terhadap nilai-nilai ajaran agama, individu tidak dapat terlepas dari pengaruh sosial budaya yang mengitarinya, sehingga menghasilkan proses akulturasi budaya. Akulturasi mengacu pada adanya pengaruh satu kebudayaan kepada kebudayaan lain atau saling mempengaruhi antara dua kebudayaan, yang mengakibatkan pada terjadinya perubahan pada kebudayaan tertentu. Proses akulturasi terjadi melalui kontak langsung antara dua kelompok yang masing-masing memiliki kebudayaan yang otonom (Soetomo, 2008:402).

\section{Hasil Penelitian}

1. Interaksi Masyarakat Muslim Senggigi dengan Kegiatan Pariwisata

Dari data yang diperoleh di lapangan menggambarkan bahwa interaksi antara masyarakat muslim Senggigi dengan para pelaku industri pariwisata sangatlah terbatas, yaitu hanya bersangkut paut dengan aspek kehidupan ekonomi dan pada saat tertentu terkait dengan aspek keagamaan. Hal itu sebagaimana diungkapkan seorang informan ketika ditanyakan mengenai hal tersebut. Menurutnya, banyak warga masyarakat yang bekerja di hotel dan kafe, termasuk anaknya yang berkerja di Cafe Metropolis yang ada di Senggigi ((Wawancara, 25 September 2017).

Informan lain juga mengungkapkan hal yang tidak berbeda ketika ditanyakan mengenai bentuk hubungan antara hotel-hotel 
dengan masyarakat sekitarnya. Ia menyatakan bahwa sebelum dibangun hotel, masyarakat sekitar mempersyaratkan agar mereka dilibatkan sebagai tenaga kerja. Sesuai dengan kemampuan yang mereka miliki, bidang yang memungkinkan adalah bukan sebagai tenaga ahli, tetapi tenaga kasar, seperti tukang dan buruh bangunan. Setelah hotelnya beroperasi ada sebagian warga yang menjadi pegawai di hotel yang bersangkutan (Suher, Wawancara, 25 September 2017).

Selain dalam bidang ekonomi, interaksi antara pihak pengelola hotel dengan masyarakat lokal berlangsung dalam aspek keagamaan. Namun, hal itu hanya berlangsung pada momentum tertentu saja, misalnya pada saat Grand Opening dan pada perayaan hari raya Qurban. Pada saat-saat tertentu, seperti pembukaan operasional hotel, pihak hotel mengundang warga sekitar, khususnya anak-anak untuk membaca surat yasin, dzikir, dan do'a. Sepulangnya, selain diberikan bingkisan kue dan nasi kotak, anakanak juga diberikan amplop berisi uang. Kalau saya sendiri tidak pernah diundang dan juga tidak pernah ikut datang ketika anakanak diundang (Suher, Wawancara, 25 September 2017). Informan lainnya menyebutkan bahwa selain mengundang anak-anak yatim untuk melaksanakan membaca surat yasin, dzikir, dan do'a, pihak hotel juga pernah berpartisipasi dalam kegiatan hari raya Qurban dengan menyumbangkan satu ekor kambing (PA, Wawancara, 29 September 2017).

Lebih dari itu, sebagaimana diungkapkan General Manajer (GM) salah satu hotel di Senggigi, pihak hotel memiliki kegiatan sosial kemasyarakatan sebagai wujud tanggung jawab sosial.

"Dalam beroperasi kami juga melaksanakan kegiatan sosial kemasyarakatan sebagai wujud tanggung jawab sosial antara lain, memberikan bantuan uang dan barang setiap bulan kepada masyarakat di empat desa sekitar seperti Mangsit, Kerandangan, Loco dan Senggigi, demikian juga setiap Ramadhan serta Idul Fitri memberikan sembako dan jika Idul Adha memberi bantuan hewan kurban kepada masing-masing desa tersebut." 
(http:/ /lombokinsider.com/industry-news/hotel-news/kilasenggigi-beach-jadi-proyek-percontohan-hotel-halal/).

Dalam bidang sosial, interaksi antara pihak hotel dengan warga sekitar tidak terjadi. Interaksi yang berlangsung adalah antara pegawai hotel secara personal dengan warga sekitar di tempattempat umum dalam bentuk saling tegur sapa. Tidak ada program sosial kemasyarakatan dari hotel yang ditujukan atau melibatkan warga lokal sekitarnya (http://lombokinsider.com/industrynews/hotel-news/kila-senggigi-beach-jadi-proyek-percontohanhotel-halal/).

Interaksi pasif seperti di atas juga berlangsung pada saat pelaksanaan ibadah shalat Jum'at. Para pegawai hotel, perusahaan travel, dan Cafe yang beragama Islam, ketika waktu shalat tiba, khususnya pada shalat Jum'at, mereka melaksanakannya di masjidmasjid yang dikelola oleh warga setempat, seperti di masjid Nurul Iman di Dusun Senggigi. Keberadaan Masjid Nurul Iman yang tidak jauh dari pusat keramaian kawasan wisata Senggi memudahkan para pekerja industri pariwisata untuk melaksakan shalat jum'at di masjid tersebut. Oleh karena itu ketika pelaksanaan shalat jum'at, jama'ah banyak. Hal itu sekaligus menambah kesemarakan pelaksanaan shalat Jum'ah sehingga jumlah jama'ahnya memenuhi masjid, bahkan sampai meluber ke teras dan halaman masjid (Observasi, 29 September 2017).

Pemandangan yang agak berbeda terlihat di Masjid Kerandangan yang letaknya jauh dari pusat keramaian wisata. Ketika pelaksanaan shalat jum'at, jumlah jamaahnya tidak sebanyak yang ada di Masjid Nurul Iman. Jamaahnya sebagian besarnya adalah warga Dusun Kerandangan dan tidak banyak terlihat jamaah yang berasal dari para pekerja di industri pariwisata. Hal itu nampak dari pakaian yang dikenakan para jamaah yang banyak menggunakan baju koko, sarung, dan berkopiah yang menggambarkan mereka sebagai warga lokal. Sebagian kecil saja yang berpakaian baju dan celana, yang menandakan mereka pekerja hotel, travel, atau supermarket yang ada di sekitarnya (Observasi, 3 Nopember 2017). 
Interaksi yang lebih intensif dan produktif sebagai bagian dari tanggung jawab sosial perusahan (CSR) antara pihak hotel dengan masyarakat lokal belum terjadi. Menurut data dari Forum "Corporate Social Responsibility" (CSR) Kementerian Sosial wilayah Nusa Tenggara Barat, dari sejumlah hotel yang ada di Nusa Tenggara Barat, baru dua hotel yang bergabung, yaitu Hotel Grand Legi dan Hotel Jayakarta. Sebagaimana dikemukakan ketua Forum "Corporate Social Responsibility" (CSR) Kementerian Sosial wilayah Nusa Tenggara Barat, Zainul Aidi, "belum ada partisipasi, baik dalam bentuk melapor maupun hadir dalam undangan, padahal kami sudah undang." (https:// mataram.antaranews.com/berita/30026/ forum-csr-ntbpertanyakan-dukungan-hotel-mengentaskan-kemiskinan)

Ungkapan di atas nampaknya senada dengan yang disampaikan oleh masyarakat yang tinggal di kawasan wisata Senggigi. Ketika ditanyakan kepada seorang informan tentang ada atau tidaknya program dari hotel yang membantu memberdayakan masyarakat sekitar. Seorang informan menyatakan bahwa sampai kini belum ada program dari hotel yang membantu untuk meningkatkan kondisi perekonomian masyarakat sekitar, misalnya dalam bentuk pelatihan. kalau kegiatan-kegiatan resmi hotel, jarang kita temukan hotel yang melibatkan masyarakat. "Yang diundang oleh hotel biasanya hanya anak yatim saja, itupun mereka hanya diundang untuk baca yasin kemudian dikasih makanan dan amplop, itupun kita tidak tahu apa isi amplopnya" (PA, Wawancara, 29 September 2017).

Senada dengan yang dikemukakan informan di atas, AZ seorang warga yang tinggal di Senggigi juga menyatakan bahwa dirinya tidak pernah diundang oleh pihak hotel terkait dengan program sosial maupun keagamaan. Ia menyatakan bahwa dirinya dan juga bapakbapak yang lainnya tidak pernah diundang dalam kegiatan yang dilaksanakan oleh hotel, baik kegiatan sosial maupun kegiatan lainnya. Menurutnya "tidak pernah, paling yang diundang hanya anak yatim untuk yasinan” (AZ, Wawancara, 29 September 2017). 
Selain dengan pihak hotel dan pelaku industri pariwisata lainnya, interaksi juga terjadi antara warga masyarakat kawasan wisata Senggigi dengan para wisatawan, khususnya yang berasal dari mancanegara. Interaksi yang terbangun lebih banyak bersifat pasif, karena memang aktifitas para wisatawan lebih banyak di pusat kegiatan wisata sehingga kurang ada interaksi dengan masyarakat lokal. Kecuali dengan warga lokal yang berkegiatan dalam industri pariwisata, maka interaksinya dengan para wisatawan mancanegara bersifat aktif. Mereka langsung berinteraksi dengan para turis asing yang memiliki pandangan hidup dan nilai budaya yang berbeda.

Sementara masyarakat yang tidak beraktifitas dalam industri pariwisata, mereka juga jarang berinteraksi dengan turis asing, bahkan ada yang tidak pernah melakukannya. Hal itu terjadi karena perkampungan warga lokal banyak terdapat di wilayah pedalaman, buka berada di pinggiran jalur utama kawasan wisata Senggigi. Mereka juga jarang keluar ke pusat-pusat keramaian wisata di mana mereka dapat berinteraksi dengan wisatawan, termasuk turis asing. Kegiatan kesehariannya lebih banyak diisi dengan aktifitas bekerja di ladang di seputaran perbukitan yang ada di kawasan Senggigi. Oleh karena itu, mereka relatif "aman" dari nilai-nilai baru yang dibawa para wisatawan, khususnya wisatawan mancanegara. Apa yang mereka miliki, yakini, dan praktikkan terkait dengan agama dan budaya tetap berlangsung seperti semula.

Kepada seorang informan ketika ditanyakan mengenai interaksinya dengan turis asing "bule" menyatakan bahwa ia jarang sekali berinteraksi karena tidak paham bahasa yang mereka gunakan. Paling sesekali kalau berpapasan di jalan mereka tersenyum dan kita balas juga dengan tersenyum. Kadangkala mereka ada juga yang cuek dengan kita, ya kita juga melakukan hal sama (Zd, Wawancara, 29 September 2017). Dengan demikian, bisa dibilang tidak terjadi interaksi atau komunikasi yang yang intens yang memungkinkan untuk terjadinya pertukaran nilai budaya.

Kondisi seperti di atas terjadi di wilayah-wilayah yang perkampungannya tidak "menyatu" dengan kawasan industri pariwisata. Di wilayah Dusun Kerandangan dan Mangsit misalnya, 
perkampungan penduduk berada jauh dari kawasan perhotelan dan pusat keramaian wisata lainnya, seperti café dan bar. Oleh karenanya interaksi antara warga dengan turis asing juga tidak berlangsung secara intensif sehingga kemungkinan terjadinya pengaruh juga kecil. Pada umumnya hotel, retoran, café, dan bar berada di "wilayah luar" di pinggiran jalan yang menyatu areanya dengan pantai, sedangkan permukiman warga banyak terdapat di "wilayah pedalaman" yang areanya yang jauh dari pantai (Observasi, 27 Oktober 2017).

Berbeda dengan warga yang secara langsung berinteraksi dengan turis asing, mereka mudah sekali "menyesuaikan diri" dengan berpenampilan seperti tampilan para turis, misalnya dalam hal berpakaian. Kondisi yang demikian itu terjadi pada para pemuda yang bekerja di industri pariwisata, khususnya di café, bar, atau "free guide". Ketika ditanyakan kepada mereka alasannya, ada yang menyatakan hanya sebagai cara memudahkan berkomunikasi dengan para turis. Informan lainnya beralasan agar lebih kelihatan modern dan ekspresi dari kebebasan (Wawancara, 29 September 2017).

2. Aktifitas Keagamaan Masyarakat Muslim di Kawasan Pariwisata Senggigi

Ada beberapa bentuk religiusitas masyarakat muslim Senggigi yang dipraktikkan dalam kehidupan mereka sehari-hari, yaitu ibadah shalat, pengajian dalam majlis ta'lim, pengajian untuk anakanak, jama'ah yasinan, dan jama'ah selakaran (pembacaan alBarzanji). Berbagai praktik peribadatan seperti di atas sekaligus mencerminkan tentang corak pemahaman keagamaan masyarakatnya.

Ibadah shalat dilaksanakan secara rutin sesuai waktu yang telah ditentukan. Hal itu ditandai dengan berkumandangnya suara adzan dari masjid-masjid yang ada di kawasan Senggigi. Namun tidak semua umat Islam melaksanakan shalatnya di masjid. Hal itu nampak dari jumlah jama'ah yang melaksanakan shalat di masjid tidak lebih dari dua baris (shaf) saja. Bahkan dalam waktu shalat tertentu, jumlah jama'ahnya lebih sedikit lagi. Fenomena seperti itu 
sebenarnya bukan hanya terjadi di kawasan wisata Desa Senggigi, tetapi merupakan kenyataan yang umum terjadi dalam masyarakat di tempat lain. Ketika shalat dzuhur misalnya, jumlah jama'ahnya hanya satu shaf saja, yang sebagian besarnya warga yang sudah berusia lanjut. Jarang terlihat adanya jama'ah yang berasal dari kalangan anak-anak dan remaja (Observasi, 20 September 2017).

Hal itu berbeda dengan yang terjadi pada pelaksanaan shalat jum'at. Sebagaimana yang terlihat di Masjid Nurul Iman di Dusun Senggigi ketika berlangsung shalat jum'ah, jamaah meluber sampai ke teras dan halaman masjid. Namun, apabila dilihat dari segi penampilan (pakaian) menunjukkan bahwa mereka bukanlah penduduk lokal. Tampilan mereka berbeda dengan penduduk lokal yang berpakaian kemeja atau baju koko, berkopiah dan bersarung. Baju dan celana yang mereka kenakan menunjukkan bahwa mereka adalah para pekerja industri pariwisata yang ada di Senggigi, seperti pegawai hotel, perusahaan travel, dan supermarket (Observasi, 29 September 2017).

Kondisi yang berlangsung di masjid Nurul Iman sebagaimana di atas terjadi karena keberadaan masjidnya di pusat keramaian industri wisata Senggigi. Hal yang berbeda terjadi di masjid Kerandangan, di mana jama'ahnya sebagian besarnya merupakan warga dusun Kerandangan. Di masjid yang sedang direnovasi total dan diperluas itu masih dapat menampung para jamaah sehingga tidak sampai meluber ke bagian luar masjid. Jamaahnya sebagian besarnya adalah warga Dusun Kerandangan dan tidak banyak terlihat jamaah yang berasal dari para pekerja di industri pariwisata. Hal itu nampak dari pakaian yang dikenakan para jamaah yang banyak menggunakan baju koko, sarung, dan berkopiah yang menggambarkan mereka sebagai warga lokal. Sebagian kecil saja yang berpakaian baju dan celana, yang menandakan mereka pekerja hotel, travel, atau supermarket yang ada di sekitarnya (Observasi, 3 Nopember 2017).

Hal lain yang terlihat dalam pelaksanaan shalat jum'at di masjid Nurul Iman adalah banyaknya jama'ah warga lokal yang sudah bergelar haji. Hal itu nampak dari pakaian yang dikenakan oleh 
sebagian jamaahnya yang menunjukkan simbol-simbol seseorang yang sudah menunaikan rukun Islam yang kelima itu. Selain memakai songkok putih (songkok haji) mereka juga mengenakan sorban yang dikalungkan di leher atau dikenakan sebagai penutup kepala membungkus songkok yang sudah dipakainya. Dapat dipastikan bahwa jamaah yang berpenampilan seperti itu adalah sudah bergelar haji atau sudah menunaikan ibadah haji ke tanah suci Makkah. Jumlah jamaah yang sudah bergelar haji cukup banyak, lebih dari dua puluh orang meskipun sebagian besarnya sudah berusia lanjut (Observasi, 27 Oktober 2017).

Pemandangan yang kurang lebih sama juga terlihat dalam pelaksanaan shalat jum'at di Masjid Kerandangan. Jumlah jamaah yang sudah bergelar haji kurang lebih sama, bahkan lebih banyak lagi yaitu mencapai tiga puluhan lebih. Tampilan mereka dapat dilihat dari pakaian yang dikenakan oleh sebagian jamaahnya yang menunjukkan simbol-simbol sebagai seseorang yang sudah menunaikan rukun Islam yang kelima itu. Selain memakai songkok putih (songkok haji) mereka juga mengenakan sorban yang dikalungkan di leher atau dikenakan sebagai penutup kepala membungkus songkok yang sudah dipakainya. Dapat dipastikan bahwa jamaah yang berpenampilan seperti itu adalah sudah bergelar haji atau sudah menunaikan ibadah haji ke tanah suci Makkah. Hal itu berbeda dengan sebagian jamaah lain yang juga memakai songkok puti tetapi tidak dilengkapi dengan aksesoris surban, maka yang bersangkutan belum bergelar haji. Jumlah jamaah yang sudah bergelar haji cukup banyak, lebih dari tiga puluh orang meskipun sebagian besarnya sudah berusia lanjut (Observasi, 3 Nopember 2017).

Kegiatan pengajian atau majlis ta'lim dipusatkan di masjid setempat dalam bentuk pengajian umum dengan menghadirkan Tuan Guru dari luar Senggigi, seperti dari Batu Layar, Sesela, Gunungsari, dan Narmada. Pelaksanaannya biasanya sebulan sekali atau sebulan dua kali, dan juga pada saat peringatan hari-hari besar Islam, khususnya pada saat perayaan maulid Nabi Muhammad saw. dan peringatan isra' mi'raj. Ketika pelaksanaan pengajiannya 
dirangkaikan dengan perayaan hari besar Islam, masyarakat yang menghadiri pengajian jumlahnya banyak. Namun, dalam pengajian rutin yang dilangsungkan setiap sebulan sekali, masyarakat yang hadir lebih sedikit (PA, Wawancara, 29 September 2017).

Kegiatan majlis ta'lim dipusatkan di masing-masing masjid yang ada di Dusun di Desa Senggigi, yaitu masjid Dusun Mangsit, Dusun Kerandangan, Dusun Senggigi, dan Dusun Loco. Ketika ditanyakan kepada informan tentang jama'ah yang hadir dalam kegiatan majlis ta'lim, informan menyebutkan bahwa peserta yang menghadiri kegiatan pengajian mayoritas adalah orang-orang tua, atau bapak-bapak dan sebagian ibu-ibu. Sedangkan remaja dan anak-anak jarang yang hadir dalam kegiatan majlis ta'lim. Mereka banyak yang hadir ketika pengajian dirangkai dengan kegiatan perayaan hari besar Islam, khususnya maulid Nabi Muhammad saw. Namun kehadiran mereka bukan menyimak isi pengajian yang disampaikan oleh Tuan Gurunya, tetapi lebih banyak beraktifitas dalam penyiapan kegiatannya, terutama perlombaan dan pembagian hadiah bagi para juaranya (PA, Wawancara, 29 September 2017).

Pengajian untuk anak-anak juga masih tetap berlangsung di masyarakat muslim Senggigi. Seorang informan, yang juga sekaligus seorang ustadz (guru mengaji) menjelaskan bahwa pada sore hari setelah selesai shalat Ashar, ia membina anak-anak untuk belajar mengaji di rumahnya. Sebagaimana yang dituturkan kepada peneliti, anak-anak yang mengaji di rumahnya adalah mereka yang sekolah kelas 5 dan 6 SD yang jumlahnya ada 25 orang (Observasi, 3 Nopember 2017).

Keberadaan wisata di kawasan Senggigi nampaknya tidak banyak membawa perubahan bagi masyarakat dalam masalah keberagamaan. Paling kurang hal seperti itulah yang dirasakan oleh masyarakat yang menjadi informan dalam penelitian ini. Ketika ditanyakan kepada mereka tentang ada atau tidaknya perubahanperubahan yang mereka rasakan dalam masalah peribadatan seiring dengan semakin pesatnya perkembangan wisata di tempat tinggal mereka. Mereka tidak terlalu risau dengan kedatangan orang-orang dari luar, baik "wisman" atau "wisnu". Nampaknya, mereka lebih 
memandang persoalan pariwisata itu sebagai persoalan ekonomi, sehingga perubahan-perubahan yang terjadi juga dilihat pada aspekaspek eknomi.

Hal di atas sebagaimana dikemukakan oleh seorang informan ketika ditanyakan kepadanya mengenai hal positif dan negatif yang dirasakannya dari perkembangan pariwisata di wilayahnya. Informan tersebut menyatakan bahwa kalau dibilang baik ya tidak, dan kalau dibilang buruk juga tidak. Hal positifnya adalah adanya "adanya sejenis perjanjian antara kepala dusun dengan pihak hotel untuk memperkerjakan warga sekitar yang ingin bekerja di hotel" (PA, Wawancara, 29 September 2017).

Lebih lanjut ia menegaskan bahwa kegiatan keagamaan tetap berjalan seperti biasanya. Dalam pengajian majlis ta'lim yang dilaksanakan dua kali dalam sebulan, jama'ah yang hadir jumlahnya selalu banyak. Namun, kadangkala juga kurang, terutama ketika masyarakat sedang sibuk bekerja, maka jumlah jama'ah yang hadir semakin berkurang (PA, W awancara, 29 September 2017).

Kesemarakan kegiatan keagamaan di Desa Senggigi juga tetap berlangsung, misalnya dalam bentuk perayaan hari besar Islam (PHBI). Sebagaimana dikemukakan seorang informan bahwa seperti halnya di tempat lain di Lombok, masyarakat muslim di Senggigi juga merayakannya dengan meriah, khususnya perayaan maulid Nabi Muhammad saw. Kegiatannya dilakukan oleh masingmasing dusun dengan diawali berbagai lomba, baik dalam bidang keagamaan maupun bidang olahraga dan permainan. Dalam bidanga keagamaan dilombakan hafalan surat pendek (juz amma), adzan, pidato, dan lainnya. Sedangkan dalam bidang olahraga dan permainan seperti sepak bola pakai sarung di lapangan becek, lari karung, sendok kelereng, makan kerupuk, dan lainnya. Puncak acaranya dilangsungkan di masjid di masing-masing dusun, yang diisi dengan ceramah agama dari Tuan Guru yang didatangkan dari luar Senggigi, termasuk dari Lombok Timur dan Lombok Tengah. Dalam puncak acara tersebut warga berbondong-bondong mengantarkan sajian makanan, baik jajanan maupun nasi (dulang 
jaje dan dulang nasi) untuk makan siang para tamu undangan di masjid (Wawancara, 29 September 2017).

Pada perayaan hari besar Islam (PHBI) lainnya juga berlangsung meriah, misalnya perayaan Idul Fitri. Dalam perayaan Idul Fitri tahun 1438 H/ 2017, masyarakat Senggigi mengawali dengan kegiatan takbir keliling di wilayah Desa Senggigi. Kegiatan ini diikuti oleh anak-anak dan remaja dari masing-masing dusun yang ada di Desa Senggigi, yaitu Dusun Loco, Dusun Senggigi, Dusun Kerandangan, dan Dusun Mangsit. Selain diikuti warga lokal, khususnya anak-anak dan remaja, panitia juga berinisiatif melibatkan para wisatawan yang sedang berlibur di kawasan wisata Senggigi dengan cara mengundang mereka untuk berpartisipasi dalam kegiatan takbir keliling. Hal itu sebagaimana dikemukakan oleh Ketua Karang Taruna Desa Senggigi, "Kami sudah menyebar undangan ke seluruh hotel dan pemilik villa yang ada di kawasan wisata Senggigi. Nanti wisatawan yang berkenan ikut dikoordinasikan oleh masing-masing manajer hotel." (https:// mataram.antaranews.com/berita/32948/warga-lombokbarat-ajak-wisatawan-pawai-takbiran)

Dalam pelaksanaannya, pawai takbir keliling berlangsung meriah. Dengan membawa obor dan miniature masjid, peserta pawai mengumandangkan takbir, tahlil, dan tahmid melalu sound sistem atau loud speaker yang telah disiapkan oleh masing-masing wakil dari masing-masing dusun. Selain diikuti oleh warga Desa Senggigi, pawai takbir keliling juga diikuti beberapa turis mancanegara. Menurut panitia dari 20 wisatawan asing yang sudah mengkonfirmasi ke panitia, hanya tujuh orang yang ikut serta. Mereka berasal dari Amerika Serikat, Belanda, Perancis, dan Selandia Baru (http://www.republika.co.id/berita/ramadhan/infomudik/17/06/24/os28ey-wisatawan-asing-ikut-pawai-takbiran-dilombok).

\section{Catatan Akhir}

Interaksi masyarakat muslim kawasan wisata Senggigi dengan kegiatan pariwisata yang berlangsung di wilayah tempat tinggalnya 
secara umum berlangsung secara pasif. Hanya pada intens berinteraksi, khususnya dengan para wisatawan. Oleh karena itu pertukaran nilai-nilai budaya hanya berlangsung pada kelompok ini. Sedangkan masyarakat pada umumnya tetap berada dalam dunia mereka yang diliputi dengan keyakinan dan tradisi agama yang dianutnya.

Keyakinan mereka itu ditunjukkan dengan ketaatan dalam melaksakan ajaran-ajaran agama dalam berbagai aktifitas keagamaan. Keberadaan pariwisata yang menghadirkan orang dengan berbagai nilai dan budaya yang beragam tidak banyak menyentuh kehidupan keberagamaan mereka. Masyarakat muslim tetap melaksanakan aktifitas keagamaan mereka sebagaimana yang telah ditunaikannya selama ini. Bahkan keberadaan Senggigi sebagai kawasan wisata menarik para aktifis dakwah, khususnya jama'ah tabligh, untuk datang dan melakukan aktifitas dakwahnya di wilayah ini.

\section{Daftar Pustaka}

Adler, Patricia A. dan Peter Adler, "Observasional Techniques", dalam Norman Denzin, K. dan Yvonna S. Lincoln (1994), Handbook of Qualitative Research (Thousand Oaks: Sage Publications, 1994).

Bogdan, Robert dan Taylor, Steven J. Pengantar Metoda Penelitian Kualitatif: Suatu Pendekatan Fenomenologis terhadap Ilmu-ilmu Sosial, ter. Arief Furchan. (Surabaya: Usaha Nasional, 1992).

Djamaluddin Ancok dan Fuat Nashori Suroso, Psikologi Islam Solusi Islam atas Problem-Problem Psikologi (Yogyakarta: Pustaka Pelajar, 1994).

Earl Babbie, The Practice of Social Research (California: Wadsworth Publishing Company, 1998).

Faisal, Sanapiah, Penelitian Kualitatif: Dasar-dasar dan Aplikasi (Malang: Yayasan Asih Asah Asuh (YA3), 1990).

H. Russel, Bernard, Research Methods in Anthropology: Qualitative and Quantitative Approaches (Walnut Creek: AltaMira Press, 1995). http:/ / senggigi.desa.id/index.php/first/artikel/102. 
Jalaludin, Psikologi Agama (Jakarta: Raja Grafindo Persada, 2001). Kartini Kartono, Patalogi Sosial (Jakarta: Raja Grafindo Persada, 2003).

Moleong, Lexy J., Metodologi Penelitian Kualitatif (Bandung: Remaja Rosdakarya, 1991).

Nasrullah R. Nazsir, Sosiologi Kajian Lengkap Konsep dan Teori Sosiologi

Sebagai Ilmu Sosial (Bandung : Widya Padjadjaran, 2008).

Nasution, S., Metode Penelitian Naturalistite Kualitatif (Bandung: Tarsito, 1992).

Nyoman S. Pendit, Ilmu Pariwisata: Sebuah Pengantar Perdana (Jakarta: Pradnya Paramita, 1999).

Pariwisata Sumbang $\quad 60 \% \quad$ PAD, dalam http://bali.bisnis.com/read/20150415/20/50981/url.

Poloutzian, F.R., Psychology of religion. (Needham Heigthts,

Massachusetts: A Simon \& Schuster Comp, 1996).

Rajasa Mu'tashim, Timbul Haryono, dan St. Sunardi, Agama dan

Pariwisata: Telaah Atas Transformasi Keagamaan Komunitas Mubammadiyah Borobudur (Yogyakarta: Pustaka Pelajar).

Riyadi Soeprapto, Interaksionisme Simbolik (Malang: Averroes Press, 2002).

Robert H. Lauer, Perspektif tentang Perubahan Sosial, ter. Alimandan (Jakarta: Rineka Cipta, 2003).

Setiadi dan Kolip, Pengantar Sosiologi: Pemahaman Fakta dan Gejala Permasalahan Sosial: Teori, Aplikasi, dan Pemecahannya. (Jakarta:

Kencana Prenada Media Grup, 2011).

Soerjono Soekanto, Sosiologi: Suatu Pengantar (Jakarta: RajaGrafindo Persada, 2007).

Soetomo, Masalab-Masalah Sosial dan Upaya Pemecahannya

(Yogyakarta: Pustaka Pelajar, 2008).

Spradley, James P., Metode Etnografi, terj. Misbah Zulfa Elizabeth

(Yogyakarta: Tiara Wacana, 1997).

Spradley, James P., Participant Observation (New York: Holt,

Rinehart, and Winston, 1980). 